\title{
Going North: Glenn Gould, Stars and the Authentic Self
}

\begin{abstract}
On December $28^{\text {th }}, 1967$, CBC aired an hour long documentary labelled the The Idea of North as part of its yearlong Canadian centennial celebration. Conceived by the well-known Canadian pianist Glenn Gould, the piece puts the voices of five speakers in dialogue by splicing and juxtaposing the text of the five, creating an aural collage which highlights common themes. The end result forms what Gould termed "Contrapuntal radio," a format he would employ again in the next two installment of The Solitude Trilogy. A brief fragment from this documentary is later sampled by Canadian indie bad Stars, to open their 2012 album The North. Whether or not Stars were overtly influenced by Glenn Gould's sound documentary is unclear. What I would like to suggests is that like The Idea of North, the album participates in a long Canadian tradition of engaging with northern themes, and thus contribute to the discursive formation of the North. Similar to the way in Gould juxtaposed the voices of his subjects, I will be taking the opening citation of The North as an invitation to put the two works in dialogue and argue that by employing a Northern discourse, often steeped in nostalgia, Stars are able to position themselves as an authentic indie band.
\end{abstract}

KEYWORDS: Canadian Identity; Popular Music; Glenn Gould; North; Nostalgia; Authenticity

o

On December $28^{\text {th }}, 1967$, CBC aired an hour long documentary called The Idea of North as part of its yearlong Canadian centennial celebration. Conceived by pianist Glenn Gould, the piece featured the voices of five interviewees-Marianne Shroeder, James Lotz, Robert Phillips, Frank Vallee and Wally McLean-who had all experienced close encounters with the northern half of the country. The broadcast's most striking feature, however, is not so much content as form. While each interview was conducted individually, Gould puts the speakers in dialogue by splicing and juxtaposing the text of the five, creating an aural collage which highlights 
common themes. Gould termed the result "Contrapuntal radio," a format he would employ again in the next two installments of The Solitude Trilogy and which straddled the divide between documentary, drama and music. Yet on my first listening of The Idea of North, it is something completely different that piqued my interest: following Gould's brief introduction, narrator Wally McLean opens with the following line: "Well the only way I see this happening is in an extended ride North" (Gould 1992). Immediately I recognized this small fragment as the introductory quotation of The North, the sixth full length studio album from Montreal Indie band Stars, released in 2012.

Whether or not Stars were overtly influenced by Glenn Gould's sound documentary is unclear. I was only able to find one interview in which the band briefly discusses The Idea of North (Gokhman 2012), though a handful of reviews do point to some of the superficial parallels between the two works (Pickard 2012; Barham 2012). What I would like to suggest instead is that like The Idea of North, the album participates in a long Canadian tradition of engaging with northern themes and thus contribute to what Sherill Grace terms the discursive formation of the North - that is, a collection of objects, themes, text etc. in which we can distinguish a commonality and which have become an integral part of Canadian identity (Grace 2001: 28). Similar to the way in Gould juxtaposed the voices of his subjects, I will be taking the opening citation of the album as an invitation to put the two works in dialogue and, taking both an aural and geographic turn, argue that by metaphorically "going north" Stars work to position themselves as an authentic indie band.

\section{Dangerous and Sublime:The North as Other}

The North has been omnipresent in discourse surrounding Canadian identity. In her book Canada and The Idea of North (2001), Sherrill Grace, drawing from the works of Michel Foucault, describes North as not only a physical location, but also as a discursive formation. A discursive formation is constituted from a "network of statements" from which we can discern certain commonalities and which are subsequently circulated and repeated (28). Statements are not limited to verbal enunciated-they can also be composed of "other representing performances" (ibid). North is thus a constantly evolving construct often used to bolster the imaged community of Canada: it is "multiple, shifting and elastic; it is a process, not an eternal fixed goal or condition" (16). Grace points to the landscape paintings of the Group of Seven, historical recounts of the Yukon Gold Rush of the 1890s, and the music of R Murray Schafer as just some manifestations of the North in Canadian history. It is within this context that we can begin to draw lines between Gould's sound documentary and Stars' album.

Glenn Gould acknowledges that this tradition of depiction and circulating the North informed his initial thinking on the subject, discovered through pouring over maps, the "romanticized, art-nouveau-tinged, Group-of-Seven paintings," and later, 
aerial photographs and geological surveys (Gould 1984: 391). His documentary is less concerned with factual representations than an excuse "to examine that condition of solitude which is neither exclusive to the north nor the prerogative of those who go north but which does perhaps appear, with all its ramification, a bit more clearly to those who have made, if only in their imagination, the journey north" (393-394). North is somewhere that can be reached without even going there and remains, as Gould himself states, "a convenient place to dream about, spin tales about, and, in the end, avoid” (Gould 1967). Stars front-man Torquil Campbell similarly acknowledges in interview that the remote nature of the North fuels its romantic potential. When asked how the North compared to the idea of "going west" in the United States, he remarks that

It's similar in the sense that it's unknown. So few people in Canada have actually been north. That's what's interesting about it, $95 \%$ of us live within 100 kilometers of the U.S. border [sic]. The north is a vast unknown in Canada. It's powerful, empty, and an intimidating place that most Canadians never see in their life. I think we were intrigued by that emptiness and distance. (Campbell interviewed in Studarus 2012)

Like Gould, Stars choose to keep the North at a distance in order to maintain its mysterious allure. Rather than an empirically defined place, both Campbell and Gould instead draw upon the discursive formation of the far North identified by Sherrill Grace in order to construct their own representations.

Where then does the North begin? For the most part, Gould locates the North as remaining firmly above the $60^{\text {th }}$ parallel with all of his subjects having journeyed there. And while, as we shall see, the North cannot so easily be pinned down, that is where we shall begin. For Stars, the song which can most easily be located at such high latitude is the title track which tells the story of an arctic explorer who slowly falls asleep in the snow, presumably to his death. Going North is here painted as a dangerous affair. The perilous North is often lurking below the surface in the Idea of North as well, whether it is Robert Phillips discussing the high rate of starvation that is found in the north, or Frank Valley describing the small settlement in which he was living as being "surrounded on each side by dangers, dangers for instance of getting lost" (Gould 1967). In his introduction, Gould states that "like all but a very few Canadians, I've had no real experience of the North. I've remained, of necessity, an outsider" (Gould 1967, emphasis added). In this construction, the North is an "Other." This othering can of course be highly problematic as "ideas of North tend to serve southern Canadian interest," often excluding the voices of those who live there (Grace 2001:16). Mickey Vallee (2013) points, for example, to some of the ways in which The Idea of North reflects the often racist discourse of White Paper Liberalism [1]. Stars' album, unsurprisingly, contains no reference to those who inhabit the North. This "other" is also gendered female, as exploring the North is the prerogative of men. This is true in The Idea of North, where four of the five (not 
counting Glenn Gould) speakers are male. Marianne Shroeder comments on the rarity of single women in the North, noting that the grand majority of women in the North have simply followed their husband there to take care of the children. Fittingly, the track "The North" is sung by the lead male vocalist of Stars, Torquil Campbell, rather than Amy Millan.

As Sherill Grace remarks, in reference to William Blair Bruce's 1888 painting The Phantom of the Snow, this is the dangerous side of the North "a deadly female space filled with ice and snow and dangerous valleys that will absorb us, destroy us by swallowing us up and transforming us-blanching and whitening-until we are one with her" (Grace 2001: 121). The North, however, not only has the potential to destroy but also to transform. In the Blair Bruce painting the phantom is clothed identically to the hunter, suggesting a slippage between the two as the hunter is overtaken by the snow (117-118). A similar effect is achieved in the song "The North" in which a ghostly presence is supplied by the voice of Amy Millan, which doubles Campbell's with increasing frequency as the song progresses. Throughout, the explorer's identity slowly slips away as he falls asleep in the snow, as evidence in the lines: "There's a person he once was/In a place far away."The lyrics also shift from third person in the chorus and first in the verse. But the specificity of "this country" and the "you can never get warm" are more ambiguous. Are these lines of dialogue coming from the explorer? Is the narrator speaking to the "explorer"? Are they, like the phantom and the hunter of the painting, one and the same? Or perhaps, the "you" refers to the third subject in play: the listener. As subject, object and viewer slowly become conflated, Stars suggests that this is not an isolated story, that in fact we are all in danger of becoming subsumed by the cold and the snow. North is allowed to drift further and further South-anywhere, in fact, "in this country."

This intimate relationship between self and other is also manifest in a very real way in The Idea of North, as the voices of the five interlocutors frequently blend together and overlap, until, as Friedman Sallis points out, it becomes almost "impossible to separate or even delineate the characters, much less understand the semantic content of their respective texts" (Sallis 2005: 122). It is in these moments that Glenn Gould's own voice emerges as his decisions to juxtapose at certain moments construct themes and narratives that would not have been immediately evident with a more straightforward documentary style. His self is thus evoked through the manipulation of others.

While the limitless quality of the North threatens to overtake, "this construction of the North necessarily contains its opposite, a friendly North of sublime beauty, abundance, natural resources waiting to be exploited, and of great spiritual power; this North is 'God's country" (Grace 2001: 17). For Stars, the containing of opposites can be found in the musical synthesis of organic and electronic, as described by bassist Evan Cranley: 
Musically, we are also trying to really balance organic and electronic music, and "Give It" was a really great example of laying down a cold and precise synthesis of organic drums and guitars. It's an interesting marriage, having the preciseness of the keyboards, and the heart of the organic thing in one place. (Cranley interviewed by Bondy 2012)

The quality of the sublime - the "vast, limitless, infinite, overwhelming, what lies beyond" (Neumann 2011:39)—is especially evident in Gould's work. Anyssa Neumann argues that Gould cultivated "a musical aesthetic of purity, order, contemplation, and endless wonder based on the idea of the Canadian North" (44). The reaching of the sublime, as a state of mind, allows not destruction but metaphorical creation and freedom. For Gould "going North" was also about "defining oneself as an individual creative agent" (Mantere 2011: 184). This sublime quality is evident to a degree The North as well: as our arctic explorer falls asleep in the snow, the narrator asks: "does he feel free?" while the song "Do you want to die together?" paints death as sublime liberation. Paradoxically, the further North you go, the more likely you are to find yourself.

\section{Canada-as-North: North as Self}

North is of course a relative direction. Throughout her book Sherill Grace points to the fluid definition of North, which while sometimes reserved to the arctic, can also refer to Northern Ontario or Quebec and sometimes to Canada as a whole. Thus, while we frequently "other" the North, we also simultaneously equate nordicity with Canadian identity (Grace 2001, 47). As the North shifts south, it's dangerous and mythical qualities dissipate. We instead find an "other" in our southern neighbours the United States. Gould was quite famously averse to many southern composers, such as Mozart, whom he famously declared died too late rather than to soon. In The Idea of North, the position of Canada-as-North is perhaps not as obvious, though R. A Phillips states that because of Canada's Northern frontier, "we've got a kind of civilization that does not conform to the rest of North America. Here is a place where non-conformists can live and flourish." In the final section of the documentary each speaker weighs in on their predictions or vision for the future of the far North. It quickly becomes evident that what they are really debating is how southern should we make the North.

In interview, Torquil Campbell also weighs in on the idea of Canada-As-North naming Toronto, among the most southern point of the country, as a "northern city." For the band, the title "is a way of reclaiming that idea of north, instead of [Prime Minister] Stephen Harper's idea of what north is, which is a fortified oil factory, basically, which exists to make money for corporations" (Campbell interviewed in Studarus 2013). In other words, Canada has been tainted by the South, and needs to return to its Northern roots. Stars are, in fact, nostalgic 
for a time when Canada was supposedly more overtly Northern. Nostalgia can be defined as "the composite feeling of loss, lack and longing" (Pickering and Keightley 2006: 921). While the original conception of the term referred largely to homesickness and thus suggested a spatial dislocation, recent usage tends to assume a yearning the past (922). Because of the tendency of nostalgia to distort the past it is referencing-usually in a positive light-nostalgia has been understood as a negative or regressive phenomena. Michael Pickering and Emily Keightley opt for a more nuanced definition, arguing that "nostalgia can only be properly conceptualized as a contradictory phenomenon, being driven by utopian impulses - the desire for re-enchantment - as well as melancholic responses to disenchantment" (936). Thus the past, in this case interpreted through the discursive formation of the North, can become a resource for the renewal of the future.

For Stars, nostalgia is both temporal and spatial. Two of the photographs featured prominently on the $\mathrm{CD}$ packaging display iconic buildings that were built as part of Expo'67 (coincidentally the same year that Gould released The Idea of North). When asked about the use of Habitat 67, Torquil locates the building temporally in a time in history which was "quixotic and utopian." The late 1960s are pinpointed as a period of history to emulate in which Canada was clearly distinguished from its southern neighbours and closer to "a Scandinavian country"-an area, of course, firmly located in the northern half of Europe (Campbell interviewed in Pete 2012). The album in many instances also sounds nostalgic, from the heavy use of synthesizer on the opening track "The Theory of Relativity," recalling the 1980s, to the opening dry arpeggiating guitar chords in "Do You Want to Die Together" which would easily seem at home in an 1950s rock ballad. Lyrics also often focus on remembering the past, rather than narrating the present. But just as Pickering and Keightley noted, nostalgia is not only about fondly remembering the past-it is also about visioning a better future. This is especially apparent in "The Theory of Relativity." While it's lyrics do indulge in the past ("Back in lame grade ten I was a total devastator, baby / Down in the schoolyard they all fell to their knees / But it can't be '93 sadly 'cause I wish it could forever") the song also tells it's listener to "Use that head and stop to think a little," before concluding with an optimistic view of the future: "You can do things they would have never dared /So don't be scared /They will do things we never dared." The (Northern) past is used as a call for action to improve the future.

Nostalgia can also be found operating in The Idea of North. The documentary is built upon reminiscence of past events, rather than explorations of present situations, moving from, as noted by Anthony Cushing, "the characters' optimistic first impressions, eventual disillusionment in the reality of the North, and 
finally, upon reflection, a wistful to return North, or nostalgia for their time there" (Cushing 2012: 29, emphasis added). Gould can be understood as nostalgic as well, though less for a time past then for the potential refuge that that North offers. The north operated "as a foil for other ideas and values that seemed to [him] depressingly urban oriented and spiritually limited" (Gould 1984: 391). Tellingly, the North is never reached in The Idea of North. Instead the documentary is about the journey there, with the sound of the train serving as a constant backdrop. Going North remains a never ending process.

\section{North as Authentic}

Why however, such an emphasis on the North on an indie pop album? The answer lies partly in the discourse of authenticity surrounding indie music, and of course, the North. Pinning down indie pop as a genre is fraught with difficulties. Short for "independent," the simplest definition of "indie" refers to any music recorded on an independent label, yet in some sense it has becomes possible to talk about indie music also possessing a distinct musical sound. The oppositional roots of indie music, however, remain evident in its usual positioning against the mass production of mainstream music. Ryan Hibbett describes indie musicians and listeners as "[a]s an elite sect within a larger field" which relies heavily on cultural capital, "to generate and sustain myths of social or intellectual superiority (Hibbett 2005: 57). Successful indie artists, in short, are those that seem authentic. Authenticity as, Emily Dolan explains, can be generated not solely in opposition to the mainstream, but also by employing certain musical practices (2010).

Here is where the North comes in as music rooted in a place is often contrasted to music that is, as John Connell and Chris Gibson argue, "placeless" and "highly commercial" (Connell and Gibson 2002, 41). With this logic, Canada-as-North equals Stars-as-North. Drawing from a Northern discourse is a way of indicating participation in a longer tradition, an active and authentic engagement with identity —one that is viewed as standing in opposition to the commercial South. This search for the authentic is also relevant for Gould who used the North as "a metaphor for things Gould regarded as indispensable for his music making: isolation, loneliness, and the ideal of artistic creation as an activity taking place outside institutions, canons and conventions of the art-world (Mantere 2012: 178). Gould was seeking to define himself on his own terms, not those of others. Yet as we have discussed, The North is not only about place, but also reaching back in time. Dolan notes that is standard practice for indie pop, which often sounds "wistfully outdated, thus preserving the memory of some distant and imaginary past" (Dolan 2010, 464). Furthermore, similar to the way the 
constructed nature of Gould's composition with voices overlapping in impossible ways leaves obvious traces of his editorial interventions, Stars' copious use of electronic sounds, which makes no pretense at attempting to sound "natural," ensure the listener that the artist is being honest. With mediation clearly evident, there is nowhere for Stars, and Gould, to hide.

As we have seen, the North is a place full of opposition: the North is at once a place of danger and the sublime, both self and other, somewhere to be avoided and embraced. Both Stars and Glenn Gould engage with these multiple and shifting definitions of North, at times aligning themselves with North, but also continually yearning for something more. The North is thus not a fixed condition, but a process. Ultimately, for both Stars and Glenn Gould the North is not simply a place, but also something to embody. For only North-through that mysterious other-can they become authentic selves.

\section{Notes}

1. The 1969 White paper, put forward by then Prime Minister Pierre Trudeau, proposed to abolish the Indian act with the view of creating a more egalitarian playing field for Aboriginal peoples. After considerable protest from prominent Aboriginal figures, the policy was eventually abandoned.

\section{References}

Barham, Ryan. 2012. "Stars - the North." The 405. http://thefourohfive.com/review/ article/stars-the-north.

Blair Bruce, William. 1888. The Phantom of the Snow. oil on canvas. $151.1 \mathrm{x} 192.1 \mathrm{~cm}$. 1888. Art Gallery of Hamilton, Hamilton. http://www.artgalleryofhamilton.com/edu/ singArt.asp? artID $=3$.

Bondy, Halley. 2012. "To North! with Canada’s Wintry Mainstays, Stars." MTV Iggy, August 1st. http://www.mtviggy.com/interviews/ to-north-with-canadas-wintry-mainstays-stars/.

Connell, John and Chris Gibson. 2002. Sound Tracks : Popular Music, Identity and Place. Critical Geographies. London ; New York: Routledge.

Cushing, Anthony. 2012. "Glenn Gould and 'Opus 2': An Outline for a Musical Understanding of Contrapuntal Radio with Respect to the Idea of North." Circuit Circuit: Musiques Contemporaines 22(2): 21-35.

Dolan, Emily. 2010. “.... This Little Ukulele Tells the Truth': Indie Pop and Kitsch Authenticity." Popular Music 29(3): 457-469.

Gokhman, Roman. 2012. "Interview: On New Album, Stars Reclaim Vision of 'The North'." The Bay Bridged, October 17. http://www.thebaybridged.com/2012/10/17/ interview-on-new-album-stars-reclaim-vision-of-the-north/. 
Gould, Glenn. 1984. The Glenn Gould Reader. Edited by Tim Page. Toronto: Key Porter Books.

1992. Glenn Gould's Solitude Trilogy Three Sound Documentaries. Perspective. Toronto: CBC Records/Les Disques SRC.

Grace, Sherrill E. 2001. Canada and the Idea of North. Montreal: McGill-Queen's University Press.

Hibbett, Ryan. 2005. "What is Indie Rock?” Popular Music and Society 28(1): 55-77.

Mantere, Juha Markus. 2012. The Gould Variations : Technology, Philosophy and Criticism in Glenn Gould's Musical Thought and Practice. Frankfurt ; New York: Peter Lang.

Neumann, Anyssa. 2011. "Ideas of North: Glenn Gould and the Aesthetic of the Sublime.” VoiceXchange 5(1): 35-46.

Pete. 2012. "Interview with Torquil Campbell." PeteHatesMusic, September $24^{\text {th }}$. http:// petehatesmusic.com/2012/09/24/interview-with-torquil-campbell-from-stars/.

Pickard, Joshua. 2012. “Album Review: Stars - the North.” Beats per Minute. http:// beatsperminute.com/reviews/album-review-stars-the-north/.

Pickering, Michael and Emily Keightley. 2006 "The Modalities of Nostalgia." Current Sociology 54(6): 919-941.

Sallis, Friedemann. 2005. "Glenn Gould's Idea of North and the Production of Place in Music." Intersections 25(1/2): 113-137.

Stars. 2012. The North. ATO Records.

Studarus, Laura. 2012. “Stars Northern Exposure." Under the Radar, July 20 ${ }^{\text {th }}$. http://www. undertheradarmag.com/interviews/stars/.

Vallee, Mickey. 2013 "Glenn Gould and the Cultural Politics of Whiteness in The Idea of North."Working Paper, University of Lethbridge, Alberta. 